\title{
Pemilihan Kode Pada Generasi Muda Non-Jawa
}

\author{
Suharyo \\ Fakultas Ilmu Budaya, Universitas Diponegoro \\ haryo.sastra@gmail.com
}

\begin{abstract}
This study aims to reveal the selection of code among the non-Javanese young generation. This is based on the many local language defense symptoms increasingly fragile. To answer the anxiety, in this study used a questionnaire technique to get the data distributed to 45 respondents, data analysis using simple percentage techniques and interpretation methods. The result, (a) the younger generation who use Indonesian as every day language in the realm of home (44.44\%), using local languages $(55.55 \%)$, (b) the language used with friends as much as $(55.55 \%)$, using the Indonesian language and using the local language as much (44.44\%), (c) languages used in older friends (77.78\%) using Indonesian language and using local languages $(22.22 \%),(d)$ respondents strongly agree $(22.22 \%)$ that Indonesian language is more important than local languages, (55.56\%) answered agree, and the rest $(22.22 \%)$ answered disagree.

Keywords: selection, language code, young generation, non-Java
\end{abstract}

\section{Intisari}

Penelitian ini bertujuan mengungkap pemilihan kode di kalangan generasi muda nonJawa. Hal ini didasari maraknya gejala pemertahanan bahasa daerah semakin rapuh. Untuk menjawab kegelisahan tersebut, dalam penelitian ini digunakan teknik angket untuk memperoleh data yang disebarkan kepada 45 responden, analisis data menggunakan teknik presentase sederhana dan metode interpretasi. Hasilnya, (a) generasi muda yang menggunakan bahasa Indonesia sebagai bahasa sehari-hari di ranah rumah $(44,44 \%)$, menggunakan bahasa daerah $(55,55 \%)$, (b) bahasa yang digunakan dengan teman sebanyak $(55,55 \%)$, menggunakan bahasa Indonesia dan yang menggunakan bahasa daerah sebanyak $(44,44 \%)$, (c) bahasa yang digunakan pada teman yang lebih tua sebanyak $(77,78 \%)$ menggunakan bahasa Indonesia dan menggunakan bahasa daerah $(22,22 \%)$, (d) responden sangat setuju $(22,22 \%)$ bahwa bahasa Indonesia lebih penting daripada bahasa daerah, $(55,56 \%)$ menjawab setuju, dan sisanya $(22,22 \%)$ menjawab tidak setuju.

Keyword: pemilihan, kode bahasa, generasi muda, non-Jawa

\section{Pendahuluan}

Masyarakat Indonesia yang kini berjumlah penduduk lebih dari 250 juta jiwa memiliki "pesona" dan "memesona" di mata dunia. Pesona Indonesia terwujud 
karena keanekaragaman yang dimiliki bangsa Indonesia. Kebudayaan yang kaya dan bergamam, bahasa yang terdiri atas 700 ratusan yang juga beragam dialeknya. Begitu juga agama dan kepercayaan yang yang beragam. Belum lagi keanekaragaman hayati. Ringkasnya, Indonesia sangat beragam. Kebereagaman masyarakat Indonesia dalam bidang bahasa memunculkan keindahan, tetapi juga kompleksitas. Kompleksitas itu tidak hanya karena adanya bahasa nasional, bahasa daerah yang beragam, tetapi juga adanya bahasa asing (khususnya bahasa Inggris). Jadi, persoalan yang dihadapi adalah masalah bahasa Indonesia, bahasa daerah, dan bahasa asing. Itulah sebabnya, Hasan Alwi dan Dendy Sugondo (2011: v) menjelaskan bahwa ada tiga masalah kebahasaan di Indonesia, yaitu (a) bahasa Indonesia, (b) bahasa daerah, dan (c) bahasa asing. Ketiga masalah tersebut tidak terlepas dari kehidupan masyarakat pendukungnya. Ketiga masalah kebahasaan tersebut sudah sering dibicarakana baik oleh pakar maupun para praktisi dan pemerhati bahasa. Secara umum mengeluhkan kedududukan, fungsi, dan peran bahasa Indonesia jika dibandingkan dengan bahasa asing. Dikatakannya, bahasa asing lebih dikenal dan lebih sering digunakan dibandingkan bahasa Indonesia. Lihatlah, misalnya, penamaan nama badan usaha, nama perumahan, dan bahkan istilah-istilah yang umum seperti download, showroom, stakeholder lebih dikenal daripada padan katanya dalam bahasa Indonesia 'unduh, ruang pamer, pemangku kepentingan'. Akan tetapi, di sisi lain; para pakar bahasa daerah mengeluh tentang keberadaan bahasa daerah yang semakin ditinggalkan penuturnya. Hal ini tentu menjadi bahan pemikiran bagi para pengambiil kebijakan dalam bidang kebahasaan. Tidak mudah memang, tetapi harus direncanakan dengan baik. Moeilono (2010) mengatakan bahwa perencanaan bahasa meliputi bidang-bidang (a) pemantapan bahasa sesuai dengan fungsinya. Misalnya, bahasa tertentu hanya digunakan untuk alat komunikasi di lingkungan tertentu (misalnya di rumah), (b) bahasa sebagai lingua franca. Akan tetapi, seperti dikemukakan di depan bahwa masyarakat penuturnyalah yang menjadi "penentu" bagi hidup/matinya suaatu bahasa. Upaya perencanaan bahasa sudah sejak kongres bahasa Indonesia dan bahasa Jawa 1 hingga sekarang telah dilakukan berbagai upaya peningkatan, pemartabatan, dan pemertahanan (khususnya bahasa daerah). Hasilnya, masih banyak hal yang perlu dilakukan, utamanya terhadap "nasib" bahasa daerah. 
Gerakan reformasi yang bergulir mulai 1998 telah mengubah paradigma tatanan kehidupan bermasyarakat, berbangsa, dan bernegara. Fenomena penggunaan bahasa di medsos kiranya dapat dijadikan contoh/cermin "kebebasan tanpa batas" di era sekarang ini tanpa ada yang mampu membendungnya (Alwi \& Sugondo, 2011). Kebebasan berekspresi berbahasa cenderung mengarah "tanpa kaidah". Diksi yang "liar", "vulgar" struktur yang "bebas" menjadi pemandangan perilaku berbahasa yang sangat sering dijumpai utamanya di medsos dan anak-anak muda. Gejala ini tampaknya memperburuk "nasib" bahasa daerah. Apalagi jika dikaitkan dengan pandangan Moeliono (2010) yang mengatakana bahwa motivasi pengalihan bahasa (dari bahasa daerah ke bahasa Indonesia) karena (1) bahasa Indonesia dikaitkan dengan kegiatan berprestise, (2) urbanisasi ke daerah perkotaan, (3) bahasa Indonesia semakin lama semakain banyak. Bahasa Indonesia dinilai dapat mewakili ekspresi "kekikinian", modern, dan "gaul”, sedangkan bahasa daerah dinilai sebaliknya "kuno dan jadul”.

Melihat gejala dan perilaku berbahasa anak-anak muda inilah penelitian (kecil) ini dilakukan. Penelitian ini mencoba melihat perilaku berbahasa di kalangan generasi muda non-Jawa, terutama yanga menyangkut bahasa yang digunakan seharihari di rumah, pemilihan kode ketika bergaul dengan teman sebaya atau dengan teman yang lebih tua usianya, dan bagaimana pandangan/sikapnya terhadap bahasa daerah dan bahasa Indonesia. Apakah nasib bahasa daerah sebagaimana dikeluhkan banyak pihak, yaitu mulai ditinggalkan penuturnya atau masih dipertahankan oleh penuturnya, generasi muda. Penelitian ini mencoba mencari jawabnya.

Masalah yang dikaji dalam penelitian ini adalah (a) pemilihan kode bahasa di kalangan generasi muda non-Jawa.Kode bahasa apa yang digunakan di ranah rumah, (b) ketika berbicara dengan teman, dan (c) sikapnya terhadap bahasa Indonesia dan bahasa daerah. Penelitian ini bertujuan mendeskripsikan pemilihan kode bahasa pada kalangan generasi muda non-Jawa (a) di ranah rumah, (b) ketika berbicara dengan teman, dan (c) sikapnya terhadap bahasa daerah dan bahasa Indonesia. 


\section{Metode}

\section{Subjek Penelitian}

Subjek penelitian ini adalah generasi muda non-Jawa. Yang dimaksud generasi muda non-Jawa dalam penelitian ini merujuk pada masyarakat/kalangan anak muda yang dihipotesiskan bahasa ibunya bukan bahasa Jawa, seperti generasi muda (masyarakat) Sunda, Jakarta, Riau, Medan; dan berusia antara 18 - 20 tahun. Dari subjek penelitian ini yang sekaligus sebagai populasi, diambil sampel yang dilakukan dengan teknik acak bertujuan, yaitu generasi muda yang bahasa ibunya bukan bahasa Jawa dan secara geografis bermukim di luar Jawa Tengah, DIY, atau Jawa Timur.

\section{Pengumpulan Data}

Data dikumpulkan melalui teknik angket. Angket yang disebarkan berisi pertanyaan yang terkait dengan (a) identitas responden, (b) bahasa sehari-hari yang digunakan, (c) bahasa yang digunakan di ranah rumah, (d) pilihan kode/bahasa ketika berbicara dengan teman sebaya/yang lebih tua, dan (e) pernyataan persetujuan terhadap penting/prestise antara bahasa Indonesia dan bahasa daerah. Angket yang disebarkan sebanyak 50 eksemplar, tetapi yang valid/kembali 45 eksemplar. Ke-45 eksemplar inilah yang dijadikan korpus data.

\section{Analisis Data}

Analisis data dilakukan dengan teknik presentase sederhana. Misal, 25 responden menjawab bahasa sehari-harinya adalah bahasa Indonesia, maka perhitungan presentasenya adalah 25: $45 \times 100 \%=55,55 \%$. Dari analisis kuantitatif ini lalu langkah selanjutnya adalah menginterpretasi aspek kualitatifnya. Mengungkap makna di balik angka-angka tersebut. Misal, melihat kondisi ini $(55,55 \%)$ telah menjadikan bahasa Indonesia sebagai bahasa sehari-hari), bahasa Indonesia sudah mulai mendominasi di ranah rumah. Hal ini sekaligus menunjukkan pemertahanan bahasa daerah sudah mulai “jebol”.

\section{Penyajian Hasil}

Laporan hasil penelitian disajikan secara informal (Sudarjanto, 1995) yang berisi "potret" pemilihan kode di kalangan generasi muda non-Jawa. 


\section{Kerangka Teoretik}

\section{Kebijakan/Politik Bahasa}

Hasan Alwi dan Dendy Sugondo (2011: v) dalam Politik Bahasa: Rumusan Seminar Politik Bahasa menjelaskan bahwa ada tiga masalah kebahasaan di Indonesia, yaitu (a) bahasa Indonesia, (b) bahasa daerah, dan (c) bahasa asing. Ketiga masalah tersebut tidak terlepas dari kehidupan masyarakat pendukungnya. Dalam berbagai publikasi dan pertemuan ilmiah sering diungkapkan yang menyangkut masalah bahasa asing yang dikatakan "membahayakan" kedudukan bahasa nasional. Dicontohkannya, papan usaha, nama-nama perumahan, nama-nama usaha lebih banyak menggunakan bahasa asing (Inggris) dibanding bahasa Indonesia. Sebaliknya, bahasa Indonesia mulai mendesak fungsi dan peran bahasa daearah. Kini sejumlah bahasa daerah ada yang sudah punah, diambang kepunahan, dan terancam punah.

Kegelisahan tentang nasib bahasa Indonesia di satu sisi dan bahasa daerah di sisi lain semakin bertambah pada saat gerakan reformasi 1998 juga telah mengubah paradigma tatanan kehidupan bermasyarakat, berbangsa, dan bernegara. Gerkan reformasi yang awalnya memunculkan sebuah harapan yang besar tentang tata kelola berbangsa, bernegara, dan bermasyarakat yang lebih baik dari era sebaliknya Akan tetapi, yang kita saksikan sekarang badalah kata reformasi telah kehilangan makna denotatifnya, yaitu 'mengubah bentuk yang lebih baik' menjadi kebebasan "tanpa batas". Bebas beripikir, berbicara, dan bertindak". Fenomena penggunaan bahasa di medsos kiranya dapat dijadikan contoh/cermin "kebebasan tanpa batas" di era sekarang ini tanpa ada yang mampu membendungnya. Jadi, kini masalah kebahasaan semakin kompleks.

\section{Kompleksitas Pemilihan Bahasa}

Kompleksitas kehidupan sosial budaya pada masyarakat Indonesia dewasa ini diyakini juga merambah pada kompleksitas kehidupan bahasa dan berbahasa di kalangan generasi muda, khususnya generasi muda non-Jawa. Kompleksitas itu, misalnya meliputi (a) kedwibahasaan dan atau kemultibahasaaan masyarakat, (b) kendala dalam pemilihan kode bahasa dalam tata pergaulan di kalangan mereka, (c) sikap/pandangan mereka terhadap bahasa daerah (bahasa pertama-nya) dan bahasa Indonesia.

Terkait dengan pemilihan bahasa, dalam berbagai literatur dijelaskan bahwa pemilihan bahasa tidak hanya sekedar memilih salah satu kode saja, tetapi terkait 
dengan berbagai hal. Hal-hal yang terkait dengan pemilihan bahasa misalnya (a) kendala sosial, (b) kendala kultural, dan (c) kendala psikologis, (d) konsep ranah, (e) diglosia, dan (f) kebocoran diglosia, serta (g) sikap bahasa. Kendala sosial pemilihan bahasa, misalnya, pada pemilihan ragam/bahasa apa yang harus digunakan dalam interaksi dengan orang tua, orang yang belum dikenal. Kendala kultural, misalnya yang terjadi pada masyarakat Jawa yang "mengharuskan" seseorang menggunakan ragam krama ketika berbicara dengan orang yang usianya lebih tua, jabatan lawan bicara yang lebih tinggi/atasan. Serentak dengan itu, pada pemilihan bahasa juga terdapat kendala psikologis, misalnya, bagaimana menjaga pikologis lawan tutur agar tidak tersinggung. Di antara kendala-kendala pemilihan kode bahasa tersebut, terdapat juga aaspek yang tak terpisahkan. Aspek-aspek itu menurut para ahli adalah keharusan memikirkan di ranah apa seseorang tersebut bertutur. Ranah rumah, ketetanggaan, pekerjaan, pendidikan, agama, dan transaksi, misalnya yang menunutut "kesesuaian" dengan pemilihan ragam/bahasa. Dari situasi tutur inilah lalu akan merujuk pada konsep diglosia, yaitu funsi dan peran bahasaa/ragam yang berbeda dalam penggunaannya. Misal, dalam ranah rumah penutur cenderung akan memilih bahasa daerah. Lain halnya, jika ada di ranah kantor/pekerjaan; penutur cenderung akan memilih bahasa nasional. Jika terjadi, "ketidaktepatan" atau "ketidaksesuaian" antara ranah dan pemilihan bahasa, peristiwa tersebut disebut telah terjadi "kebocoran diglosia". Misal, di ranah rumah "yang seharusnya" menggunakan bahasa daerah, tetapi pada praktiknya digunakan bahasa nasional. Peristiwa pemilihan bahasa/kode oleh seseorang ketika berinteraksi dengan orang lain akan dipengaruhi juga oleh sikap bahasa. Misal, ada yang mengatakan bahwa bahasa asing lebih bergengsi daripada bahasa nasional. Ada pula yang bersikap bahwa bahasa daerah dinilai lebih ekspresif dibanding bahasa nasional.

Menurut para pakar, ada tiga ciri sikap bahasa, yaitu (a) kesetiaan bahasa yang mendorong suatu masyarakat tutur untuk mempertahankan bahasanya (bahasa ibunya) dan jika perlu mencegah adanya pengaruh dari bahasa lainnya (bahasa nasional/bahasa asing); (b) kebanggaan yang mendorong orang mengembangkan dan menggunakannya sebagai lambang identitas dan kesatuaan masyarakat. Misalnya, orang Jawa akan merasa bangga jika dapat/mampu menggunakan bahasa Jawa ragam 
krama; dan (c) kesadaran akan norma bahasa yang mendorong menggunakan bahasanya dengan cermat, sesuai kaidah bahasa, dan santun.

\section{Sosiolinguistik dan Fenomena Kebahasaan}

Sosiolinguistik melihat fenomena kebahasaan sebagai fakta sosial dan menempatkannya dalam sistem lambang (kode) dan sistem tingkah laku sosial budaya. Dengan demikian, kajian sosiolinguistik menyikapi fenomena pemilihan bahasa sebagai wacana dalam peristiwa komunikasi dan sekaligus menunjukkan identitas sosial dan budaya peserta tutur ( Maifandi, 2012). Sebagai fakta sosial tentu berarti bahwa pemakaian bahasa misalnya tidak hanya dilihat hanya adari struktur dan sistem bahasa, tetapi juga "harus" ditempatkan dalam struktur dan sistem sosial yang melingkupinya. Dalam bahasa Jawa kondisi ini diungkapkan melalui ungkapan "empan papan" dan dalam peribahasa "di mana bumi dipijak di situ langit dijunjung". Artinya mempertimbangkan tidak hanya kotek, tetapi juga konteks. Sapaan pake, pak, abah, ayah, papa, mama, mom, mbok, biyung misalnya secara linguistik "hanya" merujuk pada sapaan untuk 'ayah' dan 'ibu', tetapi secara sosiolinguistik dapat dijabarkan panjang lebar.

\section{Hasil dan Pembahasan}

\section{Hasil Penelitian}

Dari penelitian yang telah dilakukan diperoleh hasil sebagai berikut.

(1) Dari 45 responen, sebanyak 20 responden (44,45 \%) mengemukakan bahwa bahasa sehari-harinya adalah bahasa Indonesia, sedangkan sisanya 25 responden $(55,55 \%)$ menggunakan bahasa daerah.

(2) Jawaban responden ketika ditanya kode/bahasa apakah yang digunakan di ranah rumah, diperoleh hasil: 20 responden $(44,45 \%)$ menggunakan bahasa Indonesia ketika berbicara dengan anggota keluarga/keluarga intinya (ayah, ibu, kakak/adiknya), dan sisanya sebanyak 25 responden $(55,55 \%)$ menggunakan bahasa daerah.

(3) Dari pertanyaan kode bahasa apa yang digunakan ketika berbicara dengan teman sebayanya? Yang menjawab mengunakan bahasa Indonesia sebanyak 25 
responden $(55,55 \%)$, dan menggunakan bahasa daerah sebanyak 20 responden $(44,45 \%)$.

(4) Ketika ditanya bahasa yang digunakan jika berbicara dengan teman yang lebih tua usianya, sebanyak 35 responden $(77,78 \%)$ menjawab menggunakan bahasa Indonesia dan 10 responden $(22,22 \%)$ menggunakan bahasa daerah.

(5) Terkait pendapat responden terhadap bahasa Indonesia dan bahasa daerah, sebanyak 10 responden $(22,22 \%)$ menjawab sangat setuju bahwa bahasa Indonesia dinilai lebih penting daripada bahasa daerah, 25 responden $(55,56 \%)$ menjawab setuju, dan 10 responden lainnya (22,22 \%) menyatakan tidak setuju.

(6) Jawaban responden ketika ditanya apakah bahasa daerah dinilai lebih penting daripada bahasa Indonesia, semua responden (100\%) menjawab tidak setuju.

(7) Ketika ditanyakan tentang persetujuannya bahwa bahasa Indonesia lebih prestise/bergengsi, sebanyak 35 responden $(77,78 \%)$ menjawab setuju, dan 10 responden $(22,22 \%)$ menjawab tidak setuju.

(8) Sewaktu ditanya pendapatnya tentang bahasa daerah lebih prestise/bergengsi daipada bahasa Indonesia, 1 responden $(11,11 \%)$ menjawab setuju dan sisanya 40 responden $(88,89 \%)$ menjawab tidak setuju.

\section{Pembahasan}

Persentase yang relatif besar $(44,44 \%)$ penggunaan kode bahasa Indonesia sebagai bahasa sehari-hari dan penggunaan di ranah rumah menunjukkan gejala telah terjadinya pergeseran dominasi bahasa daerah sebagai bahasa ibu yang selama ini menjadi bahasa sehari-hari di rumah. Bahasa Indonesia sekarang sudah menjadi pilihan sebagian besar para orang tua dan anak dalam keluarga sebagai alat komunikasi sehari-hari. Hal ini diduga terkait dengan strategi/politik bahasa nasional yang lebih mendorong masyarakat Indonesia untuk menggunakan bahasa nasional sebagai alat komunikasi. Selain itu, bahasa Indonesia secara intensif telah digunakan pada hampir semua kegiatan dan aspek kehidupan soaial budaya: surat kabar, berita di televisi, proses belajar mengajar, kampanye, dan pertunjukan seni budaya.

Jika responden yang diteliti sekarang ini (berusia 18-20 tahun) adalah generasi ke satu, maka generasi kedua hampir dapat dipastikan akan lebih banyak memilih kode bahasa Indonesia sebagai bahasa sehari-harinya (lihat Suharyo, 2017). Kondisi ini diperkuat oleh data yang menunjukkan bahasa Indonesia juga dipilih relatif besar 
sebagai alat komunikasi dengan teman sebaya dan bahkan dengan teman yang usianya lebih tua. Artinya, 50 tahun lagi (tahun 2047 - 2050-an) bahasa daerah terancam punah, atau setidaknya jumlah pemakainya tinggal sedikit. Tentu hal ini hendaknya menajdi perhatian bersama. Sebab, bahasa hendaknya tidak hanya dilihat dari sudut kebahasaan semata, tetapi dapat dilihat sebagai kekayaan budaya yang banyak mengandung nilai, petuah, kearifan lokal, dll.

Terkait temuan pernyataan responden yang menjawab sangat setuju $(22,22 \%)$ dan setuju $(55,55 \%)$ bahwa bahasa Indonesia dinilai lebih penting daripada bahasa daerah dilihat dari sisi angka tegolong besar ( karena jika digabung menjadi 77,77 \%). Dengan demikian dapat dikatakan bahwa peran bahasa Indonesia sudah sangat penting dalam kehidupan di kalangan generasi muda, khususnya generasi muda nonJawa sekaligus menggeser peran penting bahasa daerah baik dalam tataran kognisi, perkataan, dan perilaku. Lebih jauh dari itu, temuan ini menunjukkan bahwa sudah menjadi world of view di kalangan generasi muda: bahasa Indonesia lebih penting daripada bahasa daerah. Akan tetapi, penelitian ini juga menemukan data/responden yang masih menganggap bahwa bahasa Indonesia tidak lebih penting daripada bahasa daerah $(22,22 \%)$. Gejala ini dapat dimaknai bahwa sebagian generasi muda masih mencintai bahasa daerahnya. Dalam perspektif pemertahanan bahasa, responden inilah yang akan berjuang mempertahankan bahasa daerahnya dan sekaligus menjadi tumpuan harapan bagi masa depan bahasa daerahnya. Jika dinilai dari nilai-nilai sosial budaya, pada masyarakat/generasi muda non-Jawa terdapat dua nilai yang tengah diperjuangkan dan dipertahankan, yaitu nilai-nilai budaya lokal dan nilai-nilai budaya nasional/global oleh kedua "kelompok" generasi muda non-Jawa.

Ada hal menarik terkait dengan temuan di lapangan, yaitu terjadinya kontradiksi. Pada pertanyaan sebelumnya tentang derajat ke-penting-an antara bahasa Indonesia dan bahasa daerah. Data sebelumnya, dinyatakan tidak setuju oleh $(22,22$ \%) jika bahasa Indonesia lebih penting daripada bahasa daerah. Akan tetapi, ketika ditanyakan apakah setuju bahwa bahasa daerah lebih penting daripada bahasa Indonesia, semua responden (100\%) menjawab tidak setuju. Menyangkut temuan ini ada hal yang tak terbantah bahwa secara mayoritas $(77,78 \%)$ bahasa Indonesia dianggap lebih penting daripada bahasa daerah. Mengenai temuan data lainnya dapat diduga mereka $(22,22 \%)$ yang semula mengatakan tidak setujuterhadap pernyataan bahwa bahasa Indonesia lebih penting daripada bahasa daerah, menjadi "gamang" 
ketika diminta menjawab apakah bahasa daerah lebih penting daripada bahasa Indonesia. Di sisi lain, secara kualitatif bahasa Indonesia memang dinilai lebih penting dibanding bahasa daerah. Lebih jauh, dapat dimaknai secara implisit, adanya harapan dari kalangan generasi muda (yang masuk dalam 22,22 \%) agar bahasa daerah tidak punah, tetapi mereka $(22,22 \%)$ secara eksplisit mengakui (100\%) bahwa bahasa Indonesia memang dinilai lebih penting daripada bahasa daerah.

Temuan lain dalam penelitian ini adalah bahwa bahasa Indonesia dinilai lebih bergengsi $(77,78 \%)$, tetapi terdapat responden yang tidak setuju $(22,22 \%)$. Melihat hal ini, terdapat gejala yang sama dengan penilaian responden terhadap pernyataan bahwa bahasa Indonesia lebih penting daripada bahasa daerah. Ini menjunjukkan bahwa masih ada peran bahasa daerah sebagai alat pergaulan. Bahasa daerah menurut sebagian responden $(22,22 \%)$ dipandang masih memiliki kekuatan sebagai simbol sosial yang bergengsi/bermartabat. Meskipun terdapat gejala penurunan angka (11, $11 \%$ ) pada jawaban responden ketika disodori pernyataan bahwa bahasa daerah lebih bergengsi daripada bahasa Indonesia, tetapi secara kualitatif ada keinginan kuat dan pandangan bahwa bahasa daerah masih memiliki fungsi sebagai simbol sosial yang bermartabat.

\section{Simpulan}

Dari uraian ringkas di atas, dapat ditarik simpulan sebagai berikut.

(1) Kode/ Bahasa sehari-hari responden adalah bahasa Indonesia $(44,44 \%)$ dan bahasa daerah $(55,55 \%)$.

(2) Bahasa/Kode yang digunakan di ranah rumah $(44,44 \%)$ menggunakan bahasa Indonesia dan $(55,55 \%)$ bahasa daerah.

(3) Kode yang dipilih responden ketika berbicara dengan temana sebaya, sebanyak ( 55,55 \%) menggunakan bahasa Indonesia dan (44,44 \%) menggunakan bahasa daerah.

(4) Kode yang dipilih responden ketika berbicara dengan teman yang usianya lebih tua, sebanyak (77,77 \%) menggunakan bahasa Indonesia dan (22,22 \%) menggunakan bahasa daerah.

(5) Terhadap pernyataan bahwa bahasa Indonesia lebih penting daripada bahasa daerah, 22,22 \% sangat setuju, 55,55 \% menjawab setuju, dan 22,22\% menawab tidak setuju. 
(6) Sebanyak $100 \%$ responden menjawab tidak setuju jika bahasa daerah dinilai lebih penting daripada bahasa Indonesia.

(7) Sebanyak $(77,77 \%)$ responden menyatakan setuju bahwa bahasa Indonesia lebih bergengsi daripada bahasa daerah, dan 22,22 \% menyatakan tidak setuju.

(8) Terkait pernyataan bahwa bahasa daerah lebih bergengsi daripada bahasa Indonesia, sebanyak $11,11 \%$ menyatakan setuju dan $88,88 \%$ menyatakan tidak setuju.

(9) Bahasa daerah sudah mulai terdesak perannya dalam tata kehidupan generasi muda

non-Jawa sebagai alat interaksi.

(10) Bahasa Indonesia dinilai bergensi dan lebih penting daripada bahasa daerah.

(11) Bahasa daerah dinilai masih memiliki "martabat" sebagai lambang/identitas sosial di kalangan generasi muda non-Jawa meskipun secara kuantitatif angkanya relatif kecil $(11,11 \%-22,22 \%)$

\section{Daftar Pustaka}

Chaer, Abdul dan Leonie Agustina. 2004. Sosiolinguistik: Perkenalan Awal. Jakarta: Rineka Cipta.

Alwi, Hasan \& Dendy Sugono. 2011. Politik Bahasa: Risalah Seminar Politik Bahasa. Jakarta: Badan Pembinaan dan Pengembangan Bahasa, Kemendikbud.

Moeliono, Anton. 2010. Kebijakan Bahasa dan Perencanaan Bahasa di Indonesia: Kendala dan Tantangan

Pateda, Mansoer.1987.Sosiolinguistik. Bandung: Angkasa.

Fishman, J.A.1972. Sosiolinguistics-A Brief Introduction. Massachusetts Newbury House Publishers.

Sudaryanto. 1995. Linguistik: Identitasnya, Cara Penanganan Objeknya, dan Hasil Kajiannya. Yogyakarta: Duta Wacana Press.

Maifandi, Ikrimah. 2012. "Sikap Bahasa dan Pemilihan Bahasa". Dalam ikrimah maifandi.wordpress.com/https//www.google.co.id Diunduh (9 Agustus 2017). 